\title{
Occurrence of Lymphedema in Wild-Caught Anurans
}

\author{
Malcolm L. McCallum \\ P.O. Box 150, Langston, OK 73050 \\ email: malcolm.mccallum.tamut@gmail.com
}

\begin{abstract}
Lymphedema is a condition in which the lymph hearts fail to pump fluid from the lymph sacs of anurans and other amphibians. This causes the sacs to fill with fluid and provide the frog with balloon-like swellings or over-all appearance. The condition has previously been connected with various diseases including tadpole edema virus and chytrids. I observed lymphedema in six anuran species (Acris blanchadi*, Anaxyrus fowleri*, Hyla squirrela*, Pseudacris streckeri illinoensis*, Rana sylvatica, Rana sphenocephala* [species with * are species records for lymphedema]).
\end{abstract}

Keywords: lymphedema, Batrachochytrium dendrobatidis, Flavobacterium indologenes, chytrids, inflammation.

\section{Introduction}

Reports of lymphedema-like disorders in anurans are rare in the literature. This disorder, first described in 1915 (Moore, 1915) has been identified as one of the most common abnormalities in captive bred Xenopus. This lymphatic dysfunction most commonly results before or just after metamorphosis. It is characterized by extreme inflammation of tissues giving the frog a ballooned appearance. Apparently the lymph hearts fail to drain the lymph sacs and do not reach maturity (Elkan, 1976). This condition may be an inherited condition due to a recessive gene (Uehlinger, 1965, 1969). Subcutaneous lymph sac structure has been described in some anurans (Carter, 1979).

Gilbert (1942) reported abnormal inflation of the lymph sacs in a pair of male wood frogs (Rana catesbeiana) from New York. Their submandibular, ventral, and lateral lymph sacs were filled with air causing them to float helplessly and be incapable of submerging. A similar problem occurs in Illinois Chorus Frogs (Pseudacris streckeri illinoensis) in Arkansas (McCallum et al., 2001). This disorder can be confused with the build-up of fluid characteristic of lymphedema.

Captive Xenopus laevis are known to develop a lymphedema termed "hydrops" when raised in water with low salinity (Schwabacher and Elkan, 1952). Tadpoles and froglets with hydrops possess inflamed dorsal, lateral, ventral, femoral, and tibial lymph sacs. Wild-caught hydropsic bullfrog (Rana catesbeiana) tadpoles have been reported with lymphedema of only the femoral and crural lymph sacs (Hintz, 1963). A similar condition was also reported in overwintering tadpoles and frogs (Rana mucosa), (Bradford, 1984).

Iridoviruses known from amphibians are classified as polyhedral cytoplasmic amphibian viruses (PCAV). One of these groups, tadpole edema virus (TEV), mimics subcutaneous hydrops (Marcus, 1981). This virus is transmitted in the water and causes mortality in newly metamorphosed frogs. Its symptoms include subcutaneous edema, petechial hemorrhages, and necrosis in liver, kidney, gastrointestinal tract, and skeletal muscle (Faeh et al., 1998). Wolf et al. (1968) performed histopathologic analysis of edematous $R$. catesbeiana tadpoles identifying a causal agent, the tadpole edema virus (TEV). They later isolated TEV from apparently healthy $R$. catesbeiana though it could not be isolated from either Anaxyrus or Scaphiopus from the original source pond. TEV was isolated from R. catesbeiana tadpoles from Wisconsin, Alabama, West Virginia, North Carolina, and along the Mississippi River in Arkansas (Wolf et al., 1969). However, edema has also been attributed to the bacterium Flavobacterium indologenes (Olson et al., 1992) and the fungus Batrachochytrium dendrobatidis (Martel et al., 2011).

Rana catesbeiana tadpoles appear to be very sensitive to TEV (Wolf et al., 1969), but nothing is known about susceptibility of $A$. crepitans to this pathogen. They found that if the virus was added to water containing 18 day-old $R$. catesbeiana tadpoles, that death ensued beginning after 5 days of exposure. Mortality peaked at $53 \%$ by the $7^{\text {th }}$ day of this study. Forty-nine-day-old tadpoles showed first signs of mortality on the $5^{\text {th }}$ day after exposure, with mortality peaking at $37 \%$ on the $9^{\text {th }}$ day. All tadpoles were dead by the $13^{\text {th }}$ day. Clear-cut histopathology included 
necrosis of the liver, kidneys, and digestive tract. Liver necrosis was identified by the second day after exposure. Kidney necrosis and edema was expressed after the $4^{\text {th }}$ day. By the $5^{\text {th }}$ day the digestive tract started to show necrosis.

Because lymphedema is closely associated with TEV it is important to document and report its occurrence in regions where this condition has not previously been reported.

\section{Materials and Methods}

Observations of lymphedema in Acris crepitans, Pseudacris streckeri illinoensis, Anaxyrus fowleri, and Hyla chrysoceles were noted as reported. Most specimens were released, but others were anesthetized with dilute chloretone, fixed in 10\% formalin, preserved in 70\% ethanol and deposited in the Arkansas State University Museum of Zoology herpetological collection (ASUMZ), Illinois Natural History Survey collection (INHS), or the Louisiana State University at Shreveport Museum of Life Sciences (LSUSMF).

\section{Results and Discussion}

Incidence of lymphedema among wild-caught anurans was relatively low (Table 1), but was observed in 4 of 5 species in this study. Wood Frogs (Rana sylvatica) are a charismatic species of frog common in much of North America. They breed in explosive choruses over a few nights in late winter to early spring. The incidence in Wood Frogs was associated with a die-off of frogs during the breeding chorus in the Sylamore District of the Ozark National Forest in Arkansas (Trauth et al., 2000). In Wood Frogs, lymphedema ranged from the entire torso to localized single lymph sacs on the legs or patches on the back (Fig. 1).

The Illinois Chorus Frog (Pseudacris streckeri illinoensis) is a small fossorial frog that occurs in Arkansas. The range of Illinois Chorus Frogs in Arkansas has severely contracted, most likely due to precision leveling of the

Table 1. Surveys of amphibians with incidences of lymphedema.

\begin{tabular}{|c|c|c|c|c|}
\hline Location (Date) & Positive $(\mathrm{N})$ & Inspected $(\mathrm{N})$ & Species & Life Stage/s \\
\hline $\begin{array}{l}\text { Clay Co., Arkansas } \\
\text { (Feb 2001) }\end{array}$ & 1 & 40 & $\begin{array}{l}\text { Illinois Chorus Frog } \\
\text { (Pseudacris streckeri) }\end{array}$ & Adults \\
\hline $\begin{array}{l}\text { Craighead Co., Arkansas } \\
\text { (Aug } 1999 \text { - May 2003) }\end{array}$ & 0 & $>1,000$ & $\begin{array}{l}\text { Blanchard's Cricket Frog } \\
\text { (Acris blanchardi) }\end{array}$ & Adults and Juveniles \\
\hline $\begin{array}{l}\text { Hot Springs Co., Arkasnas } \\
\text { (June 2002) }\end{array}$ & 1 & 11 & $\begin{array}{l}\text { Fowler's Toad } \\
\text { (Anaxyrus fowleri) }\end{array}$ & Juvenile \\
\hline $\begin{array}{l}\text { Jane's Creek, Randolph Co., } \\
\text { Arkansas } \\
\text { (Aug. } 1999 \text { - May 2003) }\end{array}$ & 6 & $>1,000$ & $\begin{array}{l}\text { Blanchard's Cricket Frog } \\
\text { (Acris blanchardi) }\end{array}$ & $\begin{array}{l}\text { Post-metamorophic juveniles } \\
\text { and one adult }\end{array}$ \\
\hline $\begin{array}{l}\text { Sharp Co., Arkasnas } \\
\text { (Feb. 2000) }\end{array}$ & 1 & 10 & $\begin{array}{l}\text { Blanchard's Cricket Frog } \\
\text { (Acris blanchardi) }\end{array}$ & Adult \\
\hline $\begin{array}{l}\text { Stone Co., Arkansas } \\
\text { (Feb. 2000) }\end{array}$ & 5 & 140 & $\begin{array}{l}\text { Wood Frog } \\
\text { (Rana sylvatica) }\end{array}$ & Adults \\
\hline $\begin{array}{l}\text { Stone Co., Arkansas } \\
\text { (Feb. 2000) }\end{array}$ & 0 & $>500$ & $\begin{array}{l}\text { Spring Peeper } \\
\text { (Pseudacris crucifer) }\end{array}$ & Adults \\
\hline $\begin{array}{l}\text { Madison Co., Illinois } \\
\text { (Summer 1997) }\end{array}$ & 1 & 1 & $\begin{array}{l}\text { Blanchard's Cricket Frog } \\
\text { (Acris blanchardi) }\end{array}$ & Adult \\
\hline $\begin{array}{l}\text { Madison Co., Illinois } \\
\text { (July 1997) }\end{array}$ & 4 & 66 & $\begin{array}{l}\text { Southern Leopard Frog } \\
\text { (Rana sphenocephala) }\end{array}$ & Post-metamorphic juveniles \\
\hline $\begin{array}{l}\text { McLean Co., Illinois } \\
\text { (Feb - Apr. 1990) }\end{array}$ & 0 & 89 & $\begin{array}{l}\text { Blanchard's Cricket Frog } \\
\text { (Acris blanchardi) }\end{array}$ & Adults \\
\hline $\begin{array}{l}\text { Bossier Parish, Louisiana } \\
\text { (August 2004) }\end{array}$ & 1 & 5 & $\begin{array}{l}\text { Squirrel Treefrog } \\
\text { (Hyla squirrela) }\end{array}$ & metamorph \\
\hline $\begin{array}{l}\text { Ozark Co., Missouri } \\
\text { (Feb 2002) }\end{array}$ & 2 & 70 & $\begin{array}{l}\text { Blanchard's Cricket Frog } \\
\text { (Acris blanchardi) }\end{array}$ & Adults \\
\hline $\begin{array}{l}\text { Johnson Co., Missouri } \\
\text { Feb } 2012 \text { - June } 2016\end{array}$ & 0 & $>5,000$ & $\begin{array}{l}\text { Blanchard's Cricket Frog } \\
\text { (Acris blanchardi) }\end{array}$ & Adult, juvenile, metamorphs \\
\hline $\begin{array}{l}\text { Mammoth Spring, Oregon } \\
\text { Co., Missouri } \\
\text { (Feb } 2000 \text { - May 2003) }\end{array}$ & 0 & $>1,000$ & $\begin{array}{l}\text { Blanchard's Cricket Frog } \\
\text { (Acris blanchardi) }\end{array}$ & $\begin{array}{l}\text { Adults, juveniles, } \\
\text { metamorphs, tadpoles }\end{array}$ \\
\hline $\begin{array}{l}\text { Bowie Co., Texas } \\
\text { (May 2003 - Dec 2011) }\end{array}$ & 0 & $>1,000$ & $\begin{array}{l}\text { Blanchard's Cricket Frog } \\
\text { (Acris blanchardi) }\end{array}$ & $\begin{array}{l}\text { Adults, juveniles, } \\
\text { metamorphs, tadpoles }\end{array}$ \\
\hline
\end{tabular}



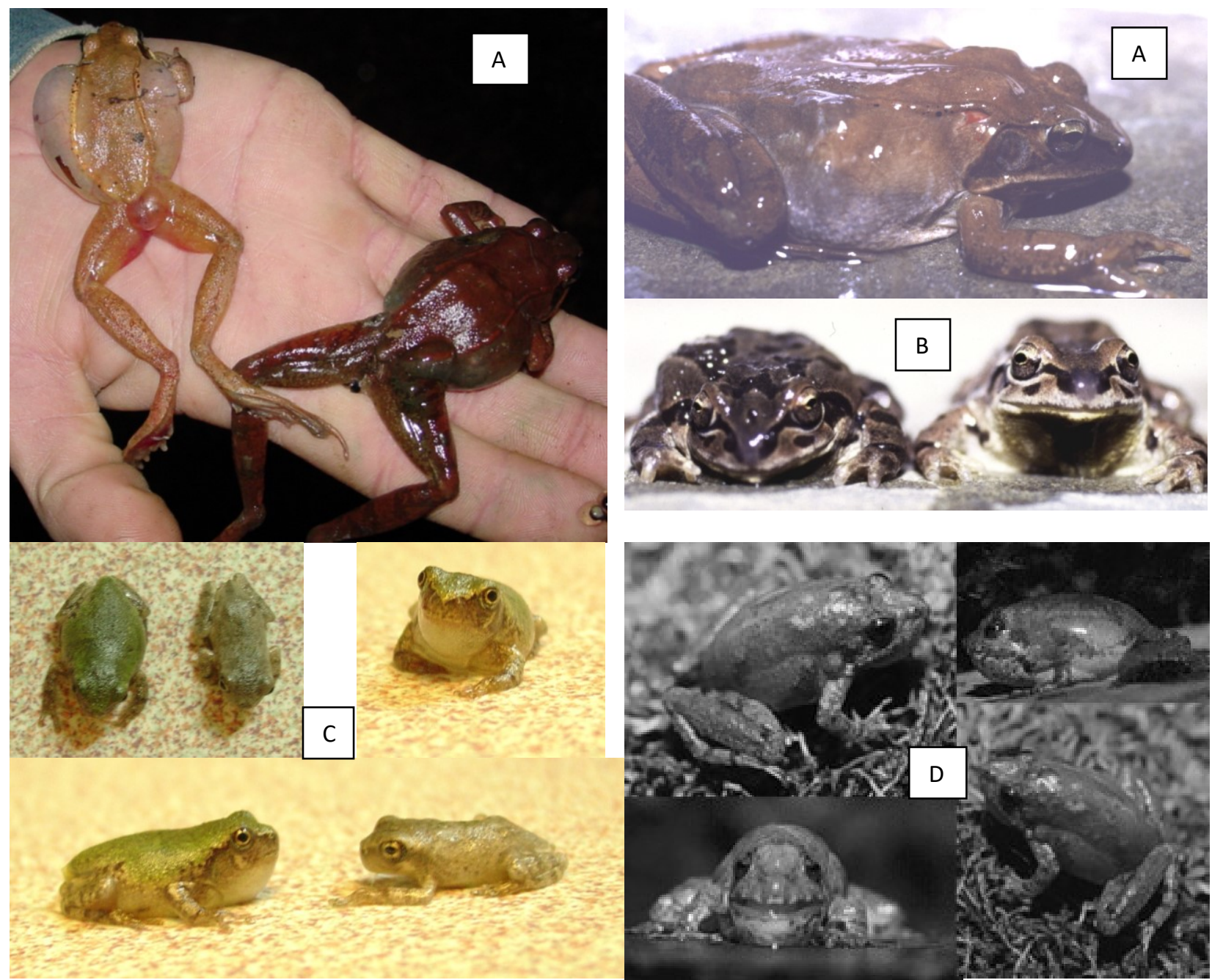

Figure 1. Lymphedema in wild-caught anurans. A) Wood Frog (Rana sylvatica) note: USGS Wildlife Disease Laboratory found no sign of disease (Green Pers. Comm). B. Illinois Chorus Frog (Pseudacris streckeri illinoensis). C. Squirrel Tree Frog (Hyla squirrela). D. Blanchard's Cricket Frog (Acris blanchardi).

farmland in which they reside (McCallum and Trauth, 2002; Trauth et al., 2006). I observed a single frog with lymphadema of the right dorsal lymph sac (Fig. 1). This individual appeared normal in movements and activity although it did not appear to be calling or acting as a satellite to other calling males (McCallum et al., 2003). Illinois Chorus Frogs were also observed with frostbite scars $(n=10)$, red inguinal pustules $(n=2)$, a dysfunctional vocal $\operatorname{sac}(\mathrm{n}=1)$, and a missing forelimb $(\mathrm{n}=1)$, (McCallum et al., 2006; McCallum et al., 2001).

The Southern Leopard Frog (Rana sphenocephala) is a generic frog species easily confused with several other species of Leopard Frogs whose ranges they overlap. They are common to creeks, grasslands, forests, and ponds throughout the Southeastern United States. Among 66 post-metamorphic Southern Leopard Frogs that were examined, a few (est. 3-4) were observed with lymphedema. However, the exact numbers were not recorded among malformed frogs in that study (McCallum, 1997), nor were possible incidences of partial lymphedema noticed because I was not aware of the condition or its connection with diseases that early in my career.

Fowler's Toad (Anaxyrus fowleri) is an average sized toad occurring across the eastern half of the United States. A single metamorph had lymphedema. It seemed otherwise normal, except that it had difficulty moving with the disorder. No Spring Peepers (Pseudacris crucifer) or Gray Treefrogs (Hyla versicolor or H. chryscocelis) were observed with the condition despite occurring in locations where other species had it (Wood Frogs, Southern Leopard Frogs, Blanchard's Cricket Frogs).

The Squirrel Treefrog (Hyla squirella) is a common arboreal frog of the Southeastern United States, although it was unknown to the Shreveport, Louisiana area at the time of this observation. We collected five near-metamphosed tadpoles at Loggy Bayou Wildlife Management (Bowie Co., Louisiana, USA) and placed them in a $20 \mathrm{~L}$ aquarium 
containing water from the collection site. They appeared morphologically normal. Upon metamorphosis, one developed lymphedema, the rest were normal. This frog died seven days later.

Blanchard's Cricket Frog (Acris blanchardi) is a small non-arboreal hylid of the eastern half of North America that can reach extraordinarily high populations on stream banks in the Ozarks and elsewhere (McCallum and Trauth, 2004; McCallum et al., 2011) which facilitates some of its unique anti-predator behaviors (McCallum, 1999; McCallum, 2011). Its taxonomic status with Acris crepitans is currently subject to debate (McCallum, 2003; McCallum and Trauth, 2006). Anatomical abnormalities in Blanchard's Cricket Frog from Arkansas have increased over the past 43 years (McCallum and Trauth, 2003) and its reproductive and growth strategies (McCallum and Trauth, 2007; McCallum et al., 2011) appears to place it at threat from climate change (McCallum, 2010). I observed large numbers of living Blanchard's Cricket Frog in five different states (Arkansas, Illinois, Louisiana, Missouri, and Texas). Addtionally, I inspected hundreds of preserved frogs from South Dakota, Nebraska, Georgia and Florida during other studies (McCallum, 2003; McCallum et al., 2011) although it was difficult to assess lymphedema in preserved specimens that had not also been seen alive. I observed more cases of lymphedema in Blanchard's Cricket Frog (Fig. 1) than in other species, but this was probably more due to sampling effort. Lymphedema was relatively rare (Table 1). These frogs were less mobile compared to non-afflicted individuals which would place them at a significant threat to predation, including from adults (McCallum et al., 2001), because their anti-predator behavior depends on rapid movement (McCallum, 2011).

Except in cases with minor lymphadema consisting of single or partial lymph sac inflammation, the disorder can be very debilitating. Frogs with extreme swelling have difficulty moving, jumping, and often remain motionless much of the time. If the disorder is caused by TEV or chytrids then it would constitute a possible method of dissemination if metamophs emerged unable to escape hungry adult frogs of the same and other species. Although the condition of lymphedema has been known for many years, it is surprising that more studies have not been conducted in the wild considering its association with amphibian pathogens and the rapidly accelerating extinction of amphibians we have already observed (McCallum, 2007; McCallum 2015).

\section{Literature Cited}

Bradford, D.F. (1984): Water and osmotic balance in overwintering tadpoles and frogs, Rana muscosa. Physiological Zoology. 57: 474-480.

Carter, D.B. (1979): Structure and function of the subcutaneous lymph sacs in the Anura (Amphibia). Journal of Herpetology 13: 321-327.

Elkan, E. (1976): Pathology in the amphians. In: Physiology of the Amphibia, Vol. III, p. 273 - 341. Lofts, B. Ed. New York, Academic Press.

Faeh, S.A., Nichols, D.K., and Beasley, V.R.. (1998): Chapter 26. Infectious diseases of amphibians. In: Status and Conservation of Midwestern Amphibians. p. 259 - 265, M.J. Lannoo Ed. Iowa City, University of Iowa Press.

Gilbert, P.W. (1942): Abnormally inflated lymph sacs in the wood frog. Copeia 1942: 177.

Hintz, H.W. (1963): Hydropsic tadpoles of Rana catesbeiana from Ohio. Journal of the Ohio Herpetological Society 4: 48.

Marcus, L.C. (1981): Veterinary biology and medicine of captive amphibians and reptiles. Philadelphia, Lea and Febiger.

Martel, A., Van rooij, P. Vercauteren, G. Baert, K. Van Waeyenberghe, L. Debacker, P. Garner, T.W.J. Woeltjes, T. Ducatelle, R. Haesebrouck, F. and Pasmans, F. (2011): Developing a safe antifungal treatment protocol to eliminate Batrachochytrium dendrobatidis from amphibians. Medical Mycology 49: 143 - 149.

McCallum, M.L. (1997): Rana sphenocephala (Southern Leopard Frog) malformities found in Illinois with behavioral notes. Transactions of the Illinois Academy of Science 92: 257 - 264.

McCallum, M.L. (1999): Acris crepitans (Northern Cricket Frog). Death feigning. Herpetological Review $30: 90$.

McCallum, M.L. (2003): Reproductive ecology and taxonomic status of Acris crepitans blanchardi with additional investigations on the Hamilton and Zuk Hypothesis. Unpublished Ph.D. thesis. Arkansas State University, Jonesboro, Arkansas.

McCallum, M.L. (2007): Amphibian decline or extinction? Current declines dwarf background extinction rates. Journal of Herpetology 41: $483-491$.

McCallum, M.L. (2010): Future climate change spells catastrophe for Blanchard's Cricket Frog, Acris blanchardi (Amphibia: Anura: Hylidae). Acta Herpetologica 5: 119 - 130.

McCallum, M.L. (2011): Orientation and directional escape by Blanchard's Cricket Frog, Acris blanchardi (Amphibia: Anura: Hylidae), in response to a human predator. Acta Herpetologica 6:161-168.

McCallum, M.L (2015) Vertebrate biodiversity losses point to sixth mass extinction. Biodiversity and Conservation 24:2497 2519.

McCallum, M.L., Brooks, C. Mason, R., and Trauth, S.E. (2011): Growth, reproduction, and life span in Blanchard's Cricket Frog (Acris blanchardi) with notes on the growth of the Northern Cricket Frog (Acris crepitans). Herpetology Notes 4: 25-35.

McCallum, M.L., Neal, R.G. and Trauth, S.E. (2003): Pseudacris streckeri illinoensis (Illinois Chorus Frog) Satellite Behavior. Herpetological Review 34: 53. 
McCallum, M.L., Trauth, S.E., McDowell, C. Neal, R.G., and Klotz, T.L. (2006): Calling site characteristics of the Illinois Chorus Frog (Pseudacris streckeri illinoensis) in northeastern Arkansas. Herpetological Natural History 9: 195 - 198.

McCallum, ML, Wheeler, BA, trauth, SE (2001): Acris crepitans (northern cricket frog). Attempted cannibalism. Herpetological Review 32: 99-100

McCallum, M.L., Wheeler, B.A., and Trauth, S.E., (2001): Pseudacris streckeri illinoensis (Illinois Chorus Frog) Dysfunctional vocal sac. Herpetological Review 32: 248-249.

McCallum, M.L. and Trauth, S.E. (2002): An investigation of the distribution and status of the Illinois Chorus Frog (Pseudacris streckeri illinoensis) and condition of breeding habitat in northeastern Arkansas: A needs assessment for conservation. Final Report to the Arkansas Game and Fish Commission, Little Rock, USA.

McCallum, M.L. and Trauth, S.E. (2003): A forty-three year museum study of northern cricket frog (Acris crepitans) abnormalities in Arkansas: Upward trends and distributions. Journal of Wildlife Diseases 39: 522-528.

McCallum, M.L. and Trauth, S.E. (2004): Blanchard's Cricket Frog in Nebraska and South Dakota. Prairie Naturalist 36: 129 136.

McCallum, M.L. and Trauth, S.E. (2006): An evaluation of the subspecies Acris crepitans blanchardi (Anura, Hylidae). Zootaxa 1104: $1-24$.

McCallum, M.L. and Trauth, S.E. (2007): Physiological trade-offs between immunity and reproduction in the Northern Cricket Frog (Acris crepitans). Herpetologica 63: 269 - 274.

Moore, A.R. (1915): An analysis of experimental edema in frogs. American Journal of Physiology. 37: $220-229$.

Olson, M. E., Gard, S., Brown, M., Hampton, R. and Morck, D.W. (1992): Flavobacterium indologenes Infection in leopard frogs. Journal of the American Veterinary Medical Association 201: 1766-1770.

Schwabacher, H. and Elkan, E. (1952): Countermeasures for difficulties observed during the breeding of Xenopus laevis in captivity. British Journal of Herpetology 1: 132-133.

Trauth, J.B., Trauth, S.E., and Johnson, R.L. (2006): Best management practices and drought combine to silence the Illinois Chorus Frog in Arkansas. Wildlife Society Bulletin 34: $514-518$.

Trauth, S.E., McCallum, M.L., and Cartwright, M.E.. (2000): Breeding mortality in the Wood Frog, Rana sylvatica (Anura: Ranidae), from Northcentral Arkansas. Journal of the Arkansas Academy of Science 54: 155.

Uehlinger, V. (1965): Une forme de goitre hérédltairechezle Batracien Xenopus laevis D. Experientla 21: 271.

Uehlinger, V. (1969): Une mutation récessive ( $p d$ ) déterminant la polydactylie chez Xenopus laevls D. (Batraciens Anoures). J. Embryol. Exp. Morphol. 21: 207-218.

Wolf, K., Bullock, G.L., Dunbar, C.E., and Quimby. M.C. (1968): Tadpole edema virus: a viscerotropic pathogen for anuran amphibians. Journal of Infectious Diseases 118: 253-262.

Wolf, K., Bullock, G.L., Dunbar, C.E., and Quimby, M.C. (1969): Tadpole edema virus: Pathogenesis and growth studies and additional sites of virus infected bullfrog tadpoles. In: Biology of Amphibian Tumors, p. 327-336. Mizell, M., Ed., New York, Springer-Verlag. 